\title{
Cephalometric changes in Class II division 1 patients treated with two maxillary premolars extraction
}

\author{
Marisana Piano Seben¹, Fabricio Pinelli Valarelli², Karina Maria Salvatore de Freitas ${ }^{3}$, \\ Rodrigo Hermont Cançado ${ }^{3}$, Aristeu Correa Bittencourt Neto ${ }^{1}$
}

Objective: The purpose of this study was to evaluate the cephalometric alterations in patients with Angle Class II division 1 malocclusion, orthodontically treated with extraction of two maxillary premolars. Methods: The sample comprised 68 initial and final lateral cephalograms of 34 patients of both gender (mean initial age of 14.03 years and mean final age of 17.25 years), treated with full fixed appliances and extraction of the first maxillary premolars. In order to evaluate the alterations due the treatment between initial and final phases, the dependent $t$ test was applied to the studied cephalometric variables. Results: The dentoskeletal alterations due to extraction of two maxillary premolars in the Class II division 1 malocclusion were: maxillary retrusion, improvement of the maxillomandibular relation, increase of lower anterior face height, retrusion of the maxillary incisors, buccal inclination, protrusion and extrusion of the mandibular incisors, besides the reduction of overjet and overbite. The tissue alterations showed decrease of the facial convexity and retrusion of the upper lip. Conclusions: The extraction of two maxillary premolars in Class II division 1 malocclusion promotes dentoskeletal and tissue alterations that contribute to an improvement of the relation between the bone bases and the soft tissue profile.

Keywords: Corrective Orthodontics. Cephalometry. Retrospective studies. Tooth extraction.

Objetivo: avaliar as alterações cefalométricas em pacientes com má oclusão Classe II, divisão 1, de Angle, tratados ortodonticamente com extrações de dois pré-molares superiores. Métodos: a amostra consistiu de 68 telerradiografias iniciais e finais de 34 pacientes de ambos os sexos (idade inicial média de 14,03 anos e idade final média de 17,25 anos), tratados com aparelho fixo completo e extrações de primeiros pré-molares superiores. Para avaliar as alterações decorrentes do tratamento entre as fases inicial e final, foi realizado o teste $t$ dependente aplicado às variáveis cefalométricas estudadas. Resultados: as alterações dentoesqueléticas decorrentes da extração de dois pré-molares superiores na má oclusão de Classe II, divisão 1, foram retrusão da maxila, melhora da relação maxilomandibular, aumento da altura facial anteroinferior, retrusão dos incisivos superiores, vestibularização, protrusão e extrusão dos incisivos inferiores, além da diminuição dos trespasses horizontal e vertical. As alterações tegumentares mostraram diminuição da convexidade facial e retrusão do lábio superior. Conclusões: a extração de dois pré-molares superiores na má oclusão de Classe II, divisão 1, propicia alterações dentoesqueléticas e tegumentares que contribuem para uma melhora da relação entre as bases ósseas e do perfil mole.

Palavras-chave: Ortodontia corretiva. Circunferência craniana. Estudos retrospectivos. Extração dentária.

${ }^{1} \mathrm{MSc}$ in Orthodontics, Inga Dental School, Maringá/PR, Brazil.

${ }^{2}$ Assistant Professor, MSc Program at Inga Dental School, Maringá/PR, Brazil.

${ }^{3}$ Post-doc in Orthodontics, University of Toronto. Assistant Professor, Inga

Dental School, Maringá/PR, Brazil.

" The authors report no commercial, proprietary or financial interest in the products or companies described in this article.
How to cite this article: Seben MP, Valarelli FP, Freitas KMS, Cançado RH, Bittencourt Neto AC. Cephalometric changes in Class II division 1 patients treated with two maxillary premolars extraction. Dental Press J Orthod. 2013 July-Aug;18(4):61-9.

Submitted: August 25, 2010 - Revised and accepted: May 03, 2011

Contact address: Fabrício Pinelli Valarelli

Rua Manoel Pereira Rolla, 12-75 - Apto 503 - Bauru/SP - Brazil

CEP: 17012-190 - E-mail: fabriciovalarelli@uol.com.br 


\section{INTRODUCTION}

Nowadays, the protocol for Class II treatment with extraction of two maxillary premolars is the second most used protocol of extraction in orthodontic treatments $(20.2 \%)$, being only inferior to the protocol of extraction of the four first premolars (42.9\%). It is especially recommended when there is no cephalometric discrepancy and severe crowding on the lower arch. This treatment protocol favors the patient regarding to collaboration on the use of anchorage reinforcement, once it will be required a shorter period of use of such appliances. ${ }^{12}$

Some authors speculate that dental extractions may cause some problems to the patient such as: Temporomandibular disorder, ${ }^{2,6}$ lack of treatment stability, ${ }^{10,17}$ and unwanted profile flattening, which would compromise the patient's esthetics by the end of the treatment. ${ }^{22,23}$ However, other authors point the numerous favorable results obtained on treatment with extraction of two upper premolars with good occlusal stability in the long term ${ }^{13,14}$ and without direct influence on the flattening of the patient's profile. .11,12,15

The cephalometric alterations promoted by this treatment protocol and often mentioned in literature are: Increase of nasolabial angle, retraction of upper lip, reduction of profile convexity and retraction with verticalization of upper incisors, ${ }^{24-27}$ i.e., the orthodontic treatment with extractions of maxillary premolars has little influence in relation to skeletal changes and provides greater dental and profile alterations.

Nevertheless, some doubts and questioning still persist about the real impact of extraction of upper premolars on skeletal, dentoalveolar and tissue components of patients with Class II malocclusion. Before that, this work aims to assess the cephalometric, dentoalveolar and tissue alterations in patients with Angle Class II malocclusion, division 1, orthodontically treated with extraction of two maxillary premolars.

\section{MATERIAL AND METHODS}

Material

The sample used in this retrospective study consisted of 68 initial and final teleradiographs of 34 patients (15 females, 19 males, mean age of 14.03 years \pm 2.65 , with amplitude of 10.83 to 25.83 ) treated on the course of specialization in Orthodontics at Uningá, Bauru, for a mean period of $3.21 \pm 1.43$ years, with amplitude of 1.25 to 7.83 and finished the orthodontic treatment with a final mean age of $17.25 \pm 2.59$ years, with amplitude of 13.49 to 28.24.

The criteria for inclusion of patients in the selected sample was based on presence of the following characteristics: Angle Class II malocclusion division 1 with molar relation of at least $1 / 2$ Class II (cuspto-cusp relation), absence of crowding or with mild crowding, presence of all permanent teeth erupted until the first premolars, overjet of at least $5 \mathrm{~mm}^{4,25}$ and orthodontically treated with extractions of upper first premolars. Patients with Class II malocclusion subdivision were excluded from the sample.

Patients in the sample were treated with Edgewise technique braces, slot $0.022 \times 0.028$-in. The most used sequence of alignment and leveling was 0.015 -in twist-flex or 0.014-in NiTi at the beginning of treatment, followed by arches 0.016, 0.018 and 0.020-in of stainless steel. For the anterior superior retraction phase it was used the arch $0.019 \times 0.025$-in of stainless steel and some patients used during this phase intermaxillary elastics of Class II and/or headgear for anchorage reinforcement. By the end of active treatment, the patients used a Hawley plate on the upper arch and a retainer $3 \times 3$ attached on the lower arch.

\section{Methods}

Lateral teleradiographs were obtained from all patients at the beginning $\left(\mathrm{T}_{1}\right)$ and end $\left(\mathrm{T}_{2}\right)$ of the orthodontic treatment. These teleradiographies were obtained in 4 different radiographic units that presented magnification factors ranging from 6 to $9.8 \%$.

The teleradiographies were scanned with flatbed scanner Microtek ScanMaker i800 (9600 x 4800 dpi, from Microtek International, Inc., Carson, CA, USA) and attached to a microcomputer Pentium. The images were transferred to Dolphin Imaging Premium 10.5 (Dolphin Imaging \& Management Solutions, Chatsworth, $C A, U S A$ ) through which it were unmarked the points by the same examiner and it were performed the measurements of skeletal, dental and tissue measures (Figs 1, 2, and 3).

\section{Skeletal cephalometric measures}

»SNA $\left({ }^{\circ}\right)$ : Angle formed by lines SN and NA. It indicates the sagittal relation of the maxilla in relation to the skull base. 


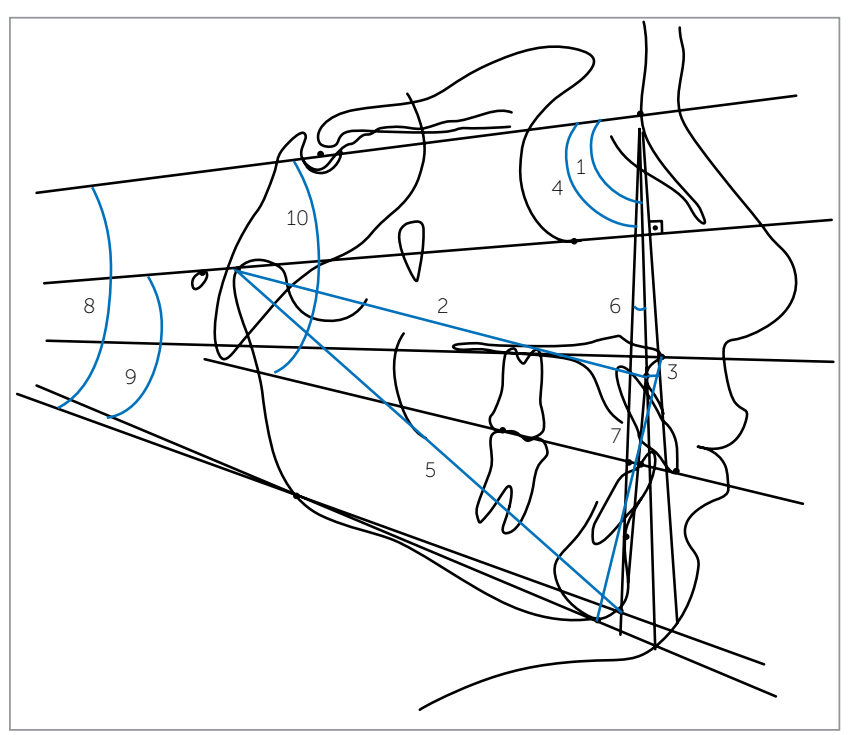

Figure 1 - Skeletal cephalometric measures: 1) SNA ( $\left.{ }^{\circ}\right)$; 2) Co-A (mm); 3) ANperp (mm); 4) SNB $\left({ }^{\circ}\right)$; 5) Co-Gn $(\mathrm{mm})$; 6) ANB $\left({ }^{\circ}\right)$; 7) AIFH (mm); 8) SNGoGn $\left({ }^{\circ}\right)$; 9) FMA $\left({ }^{\circ}\right)$; 10) SN.OCl $\left({ }^{\circ}\right)$.

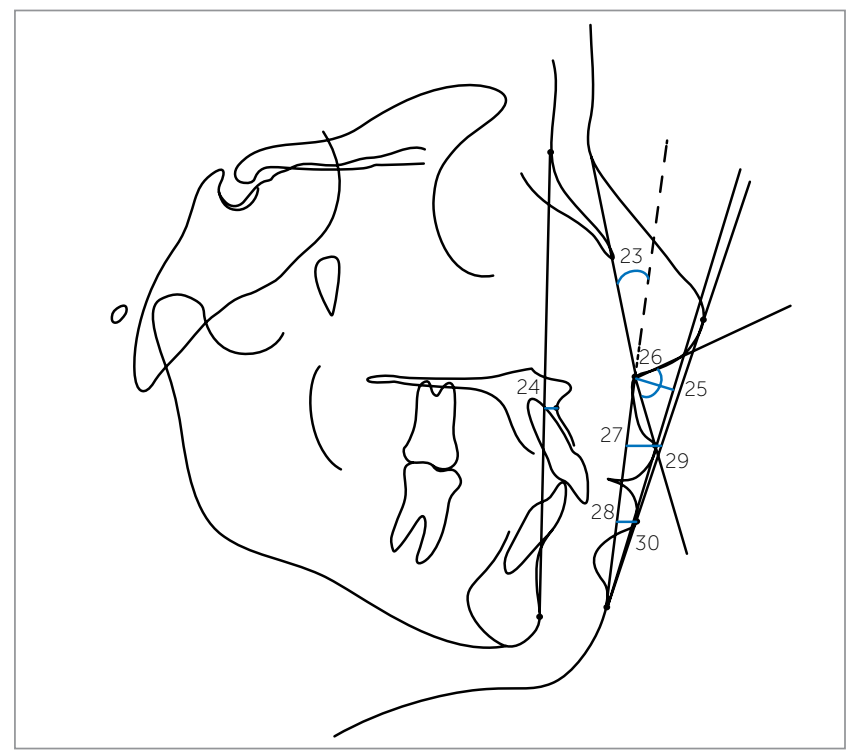

Figure 3 - Tissue cephalometric measures: 23) G'Sn.Pog' $\left({ }^{\circ}\right)$; 24) A-NPog (mm); 25) Sn-H (mm); 26) ANL ( $\left.{ }^{\circ}\right)$; 27) UL-SnPog (mm); 28) LL-SnPog (mm); 29) UL-E (mm); 30) LL-E (mm).

»Co-A (mm): Distance between the points Condyle and A. It represents the effective length of the mean face (maxilla).

»A-Nperp (mm): Distance between the point A and the line $\mathrm{N}$ perpendicular to Frankfurt's plane. It defines the sagittal position of the maxilla.

» SNB $\left({ }^{\circ}\right)$ : Angle formed by lines SN and NB. It indicates the sagittal relation of the mandible in relation to the skull base.

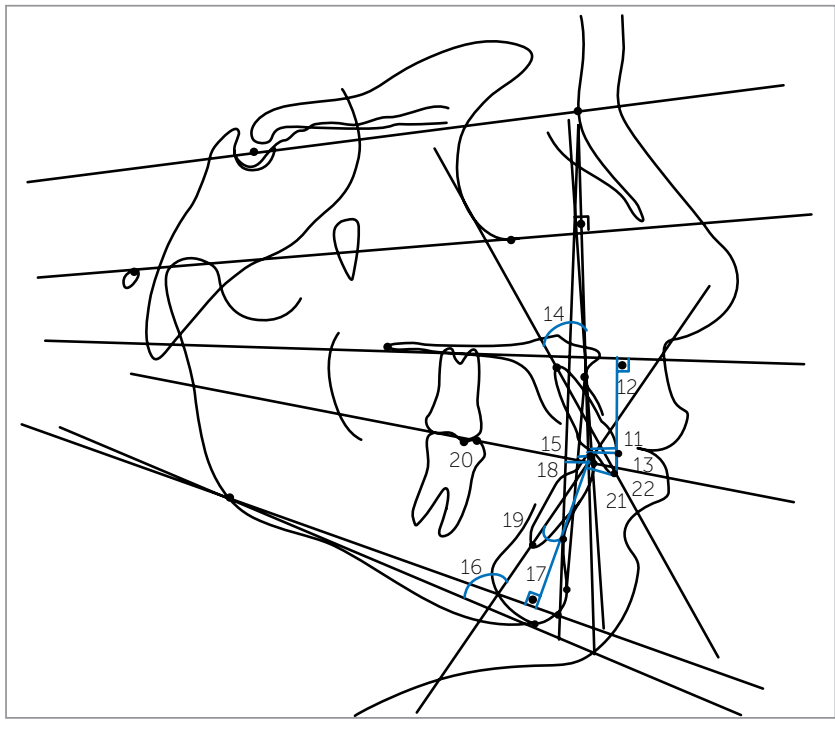

Figure 2 - Dental cephalometric measures: 11) 1-Aperp (mm); 12) 1-PP (mm): 13) 1-NA (mm); 14) 1.NA $\left({ }^{\circ}\right)$; 15) 1-AP (mm); 16) IMPA $\left({ }^{\circ}\right)$; 17) 1-GoGn (mm) 18) 1-NB (mm); 19) 1.NB ( ${ }^{\circ}$; 20) Molar relation (mm); 21) Overbite (mm); 22) Overjet (mm).

» Co-Gn (mm): Distance between the points Condyle and Gnathion. It defines the effective mandibular length.

»ANB $\left({ }^{\circ}\right)$ : Angle between the lines NA and NB. It represents the degree of sagittal discrepancy between maxilla and mandible.

"SN.GoGN $\left({ }^{\circ}\right)$ : Defines the orientation of facial growth pattern.

» FMA $\left({ }^{\circ}\right)$ : Angle formed by Frankfurt's and mandibular planes.

»OP.SN $\left({ }^{\circ}\right)$ : Angle formed between the line SN and the occlusal plane. It relates the occlusal plane inclination to the skull base.

»AIFH (mm): Distance between the points anterior nasal spine and mentalis. It indicates the height of the lower third of the face.

\section{Dental cephalometric measures}

"1-Aperp (mm): Distance from the vestibular portion of the upper central incisor to the line A-perp.

"1-PP (mm): Distance between the incisal edge of the upper central incisor and the palatal plane perpendicularly measured. It relates the vertical positioning of the upper incisor to the maxilla.

"1-NA ( $\mathrm{mm})$ : Distance between the anterior point of the crown of upper central incisor and the line NA. It relates the sagittal position of upper incisor in relation to maxilla and to Nasion. 
»1.NA $\left({ }^{\circ}\right)$ : Angle between the long axis of upper central incisor and line NA. It defines the degree of inclination of the central incisor in relation to maxilla and Nasion.

"1-APog (mm): Distance from the incisal edge of lower incisor to line Apog.

"IMPA $\left({ }^{\circ}\right)$ : Angle between the long axis of lower central incisor and the mandibular plane GoMe. It indicates the inclination of this tooth in relation to the mandible.

"1-GoGn (mm): Distance from incisal edge of lower incisor to mandibular plane GoGn, measured perpendicularly to this plane.

"1-NB (mm): Distance between the anterior point of the crown of lower central incisor and line NB. It relates the sagittal position of lower incisor in relation to mandible and Nasion.

"1.NB $\left({ }^{\circ}\right)$ : Angle between the long axis of lower incisor and line NB. It relates the inclination of this tooth to the mandible and Nasion.

"Molar relation $(\mathrm{mm})$ : Distance between the mesial cusp of upper and lower first premolars perpendicularly projected on the occlusal plane.

"Overbite $(\mathrm{mm})$ : Distance between the incisal edges of upper and lower central incisors measured perpendicularly to the occlusal plane.

" Overjet $(\mathrm{mm})$ : Distance between the incisal edges of upper and lower central incisors perpendicularly projected to the occlusal plane.

\section{Tissue profile}

" UL-SnPog (mm): Distance from the upper lip to line Subnasal Pogonion.

" LL-SnPog (mm): Distance from the lower lip to line Subnasal Pogonion.

» UL-E (mm): Distance from the upper lip to line Pronasal Pogonion.

» LL-E (mm): Distance from the lower lip to line Pronasal Pogonion.

» ANL - nasolabial angle: Formed by lines columella to Subnasal and from Subnasal to upper lip.

» G'.Sn.Pog' $\left(^{\circ}\right)$ : Facial convexity angle. It's formed by lines tissue glabella to Subnasal and from Subnasal to tissue Pogonion.

"A-NPog (mm): Distance from point A to line Nasion to the Pogonion.

» $\mathrm{Sn}-\mathrm{H}(\mathrm{mm})$ : Shortest distance from point Subnasal to line $\mathrm{H}$ of Holdaway (Pogonion to upper lip).
For evaluation of intraexaminer error, 20 teleradiographs randomly selected were scanned and measured again after a minimum interval of 4 weeks. For evaluation of systematic error, it was applied the dependent t test and the magnitude of random error was calculated by Dahlberg's formula.

It was performed the evaluation of data normality through Kolmogorov-Smirnov test. The results showed that all variables presented normal distribution. This way, it was applied the dependent $t$ test on the studied cephalometric variables to verify alterations due treatment between initial $\left(\mathrm{T}_{1}\right)$ and final $\left(\mathrm{T}_{2}\right)$ phases. The statistical analysis was performed with Statistica for Windows (Statistica for Windows - Release 7.0 - Copyright Statsoft, Inc. 2005). It were considered statistically significant the results with $p$ value of $p<0.05$.

\section{RESULTS}

Among the 30 studied cephalometric variables, only 3 presented significant systematic error (FMA, 1-PP and IMPA). The magnitude of random errors ranged from 0.22 (overjet) to 2.12 (IMPA). The results are displayed on Table 1.

Patients with Class II malocclusion, division 1, treated with extraction of two upper premolars presented the following cephalometric alterations: maxillary retrusion in relation to the skull base, increase on the mandibular length and anterior inferior facial height (AIFH), improvement on the maxillomandibular relation, upper incisors retrusion, vestibularization and protrusion of the lower dentoalveolar component, improvement on molar relation, reduction of overbite and overjet, reduction of facial convexity and upper lip retrusion.

\section{DISCUSSION}

Evaluating the results found in this work it is possible to establish and assess the alterations caused on dentoskeletal and tissue components due the extraction of upper first premolars, in Class II division 1 patients.

Regarding the maxillary component, the maxilla experienced a significant retrusion noticed by the statistically significant reduction of variables SNA and ANPerp (Table 1). The reduction of these variables occurred due the necessity of correction of Class II relation of canines and overjet normalization, due the use of intermaxillary elastic and EOA as anchorage reinforcement. 
Table 1 - Results of dependent t test comparing initial phase $\left(T_{1}\right)$ and final phase $\left(T_{2}\right)$ of treatment.

\begin{tabular}{|c|c|c|c|c|}
\hline \multirow{2}{*}{ Variables } & Initial $\left(\mathrm{T}_{1}\right)$ & Final $\left(\mathrm{T}_{2}\right)$ & \multirow{2}{*}{$\begin{array}{c}\text { Difference } \\
\left(T_{2}-T_{1}\right)\end{array}$} & \multirow{2}{*}{$\mathbf{p}$} \\
\hline & Mean \pm SD & Mean \pm SD & & \\
\hline \multicolumn{5}{|c|}{ Maxillary component } \\
\hline SNA (degrees) & $75.66 \pm 4.73$ & $74.15 \pm 3.96$ & -1.51 & $0.017^{*}$ \\
\hline Co-A (mm) & $84.21 \pm 5.12$ & $85.00 \pm 5.00$ & 0.78 & 0.084 \\
\hline A-Nperp (mm) & $0.19 \pm 3.46$ & $-1.06 \pm 3.60$ & -1.26 & $0.024^{*}$ \\
\hline \multicolumn{5}{|c|}{ Mandibular component } \\
\hline SNB (degrees) & $70.79 \pm 3.99$ & $70.55 \pm 3.57$ & -0.24 & 0.569 \\
\hline Co-Gn (mm) & $107.50 \pm 6.39$ & $111.55 \pm 5.95$ & 4.05 & $0.000 *$ \\
\hline \multicolumn{5}{|c|}{ Maxillomandibular relation } \\
\hline ANB (degrees) & $4.87 \pm 2.58$ & $3.61 \pm 2.20$ & -1.27 & $0.001^{*}$ \\
\hline \multicolumn{5}{|l|}{ Vertical component } \\
\hline SN.GoGn (degrees) & $30.55 \pm 5.59$ & $30.90 \pm 5.61$ & 0.35 & 0.338 \\
\hline FMA (degrees) & $24.44 \pm 4.21$ & $24.54 \pm 4.49$ & 0.10 & 0.777 \\
\hline OP.SN (degrees) & $11.41 \pm 4.12$ & $12.49 \pm 4.21$ & 1.08 & 0.016 \\
\hline $\mathrm{AlFH}(\mathrm{mm})$ & $62.60 \pm 4.39$ & $64.93 \pm 4.56$ & 2.33 & $0.000 *$ \\
\hline \multicolumn{5}{|c|}{ Upper dentoalveolar component } \\
\hline 1-Aperp (mm) & $7.68 \pm 2.23$ & $5.22 \pm 2.18$ & -2.45 & $0.000 *$ \\
\hline $1-P P(m m)$ & $26.65 \pm 2.37$ & $26.98 \pm 2.60$ & 0.33 & 0.373 \\
\hline 1-NA (mm) & $6.49 \pm 3.17$ & $4.48 \pm 2.67$ & -2.02 & $0.001^{*}$ \\
\hline 1.NA (degrees) & $25.23 \pm 6.76$ & $22.76 \pm 5.19$ & -2.47 & 0.080 \\
\hline \multicolumn{5}{|c|}{ Lower dentoalveolar component } \\
\hline 1-APog $(\mathrm{mm})$ & $1.91 \pm 1.81$ & $3.81 \pm 1.76$ & 1.89 & $0.000^{*}$ \\
\hline IMPA (degrees) & $86.21 \pm 5.36$ & $89.65 \pm 6.38$ & 3.43 & $0.001^{*}$ \\
\hline 1-GoGn (mm) & $36.40 \pm 2.74$ & $37.36 \pm 2.30$ & 0.96 & $0.016^{*}$ \\
\hline 1-NB (mm) & $5.93 \pm 1.79$ & $7.22 \pm 1.57$ & 1.28 & $0.000 *$ \\
\hline 1.NB (degrees) & $24.60 \pm 4.16$ & $28.13 \pm 5.04$ & 3.52 & $0.000 *$ \\
\hline \multicolumn{5}{|l|}{ Dental relations } \\
\hline Molar relation & $2.89 \pm 1.32$ & $4.45 \pm 0.83$ & 1.56 & $0.000 *$ \\
\hline Overbite & $2.90 \pm 2.92$ & $1.78 \pm 1.12$ & -1.13 & $0.011^{*}$ \\
\hline Overjet & $7.63 \pm 1.59$ & $2.32 \pm 0.84$ & -5.31 & $0.000 *$ \\
\hline \multicolumn{5}{|l|}{ Tissue profile } \\
\hline UL-SnPog (mm) & $5.60 \pm 1.55$ & $4.35 \pm 1.45$ & -1.25 & $0.000 *$ \\
\hline LL-SnPog (mm) & $3.81 \pm 1.80$ & $3.62 \pm 1.83$ & -0.19 & 0.468 \\
\hline UL-E (mm) & $-0.37 \pm 2.20$ & $-2.65 \pm 2.12$ & -2.28 & $0.000 *$ \\
\hline LL-E (mm) & $0.77 \pm 2.09$ & $-0.07 \pm 2.24$ & -0.85 & $0.004 *$ \\
\hline ANL (degrees) & $97.57 \pm 7.06$ & $99.64 \pm 7.51$ & 2.07 & 0.072 \\
\hline G'Sn.Pog' (degrees) & $18.48 \pm 4.73$ & $16.96 \pm 4.80$ & -1.52 & $0.000 *$ \\
\hline A-NPog (mm) & $0.19 \pm 3.46$ & $-1.06 \pm 3.60$ & -1.26 & $0.024^{*}$ \\
\hline $\mathrm{Sn}-\mathrm{H}(\mathrm{mm})$ & $7.33 \pm 2.01$ & $5.74 \pm 1.83$ & -1.59 & $0.000 *$ \\
\hline
\end{tabular}

*Statistically significant difference for $p<0.05$.

It is notable that the antero-superior teeth retraction may affect the positioning of point $\mathrm{A}$ in relation to the skull base..$^{4,25}$

Scott Conley and Jernigan ${ }^{25}$ also observed a statistically significant reduction of the variable A-Nperp in cases treated with extraction of two upper premolars. However, Rains and $\mathrm{Nanda}^{24}$ did not find significant alterations on point A. But in this study the variable Co-A did not present statistically significant alteration. It is speculated that there was no alteration due the fact that most patients were in growth stage, which disguised the retraction experienced by point $A$.

On the mandibular component, it was evidenced a significant increase of the mandible effective length (Co-Gn) 
(Table 1). This was expected since the evaluated patients in this research were in growth stage, as explained above. In this study, this increase was greater than the expected being corroborated by some authors that reported similar results in literature. 4,7,23 $^{-1}$

On the maxillomandibular relation, there was a significant alteration of the anteroposterior skeletal discrepancy, shown by the reduction of angle ANB (Table 1). This alteration was expected because the orthodontic treatment aimed the correction of Class II malocclusion and of the overjet initially increased by upper incisors retraction. Besides, the potential of mandibular growth on this age group helps the reduction of angle ANB. ${ }^{25,26}$ Tadic and Woods ${ }^{26}$ observed that the greater the overjet at the beginning of treatment, greater the probability of reduction of angle $\mathrm{ANB}$, in cases treated with extraction of two upper premolars. Oliveira et $\mathrm{a}^{20}$ observed that there was improvement on the anteroposterior maxillomandibular relation, shown by the reduction of ANB. Scott Conley and Jernigan ${ }^{25}$ also observed a statistically significant reduction of the angle ANB contributing for an improvement of the existent relation between dental arches, and a significant increase of AIFH as occurred in the present study.

In the work by Chua, Lim and Lubit ${ }^{5}$ it was found an increase of AIFH associated to a clockwise rotation of the mandible only in cases treated without dental extractions, while in treatments with extractions it was not observed any significant alteration on AIFH. Differently from the findings of these authors, most works found in literature are in agreement with the present study, in which AIFH presented a statistically significant increase during treatment. It is believed that the responsible for this alteration was the potential growth still present in patients and the orthodontic mechanics that used intermaxillary elastics during closing of spaces after extractions. Some authors observed that the increase of the lower third of the face is related to age and growth potential of the patients, besides the use of intermaxillary elastics. ${ }^{19}$ On the work by Oliveira et $\mathrm{al}^{20}$ the AIFH increased due the compensatory extrusion of molars during anterior retraction phase. Now Merrifield and $\mathrm{Cross}^{19}$ emphasized that any mechanics that promote dental extrusion causes the increase of AIFH.

On the variables related to growth pattern, both SN.GoGn and FMA did not present statistically significant alterations between initial and final phases of treatment (Table 1). Scott Conley and Jernigan ${ }^{25}$ also did not find significant alterations in relation to the change on growth pattern in cases treated with extraction of two premolars. The variable OP.SN presented a statistically significant increase during treatment. This increase does not mean in alteration of growth pattern impressing a vertical characteristic for the patients, because the other variables of this component did not present significant alteration. It is believed that the alterations observed on the variable OP.SN are related to dentoalveolar changes, for instance, the curve of Spee flattening, occurred during the treatment of patients. At the beginning of treatment, it is frequently observed an accented extrusion of lower incisors due to increased overjet. ${ }^{18,28}$ During treatment there was flattening of curve of Spee, which led to a clockwise rotation of the occlusal plane. This effect was enough to promote statistically significant change of variable OP.SN being only a reflex of dental alterations and not skeletal since the other variables, SN.GoGn and FMA, that characterize the component, did not present statistically significant changes.

The study by Oliveira et $\mathrm{al}^{20}$ showed compensatory extrusion of molars during retraction phase in cases with extraction of four premolars, and also did not report statistically significant differences on variables SN.GoGn and SN.GoMe that characterized the growth pattern.

On the upper alveolar component, the upper incisors presented a statistically significant retrusion (1-Aperp, 1-NA). There was no significant alteration of upper incisors on the vertical direction or in relation to inclination (1-PP and 1.NA, respectively) (Table 1). According to several authors, the skeletal effects of the treatment were more evident on the maxilla and on the superior teeth than in the mandible or lower teeth, in cases treated with extraction of two upper premolars. ${ }^{25,27}$

Tadic and Woods ${ }^{26}$ verified a significant increase on the inclination of upper incisors related to line N-A also in cases with extraction of two upper premolars and observed that the greater the overjet at the beginning of treatment, greater the probability of reduction of upper incisors inclination, and that the greater the reduction on angle ANB, smaller the necessity of reduction of upper incisors inclination. In this work there was no significant difference between the inclination of 
upper incisors at the beginning and end of treatment, which differs from most works with extraction of two premolars. It can be asserted that there is a tendency of these teeth to obtain a more palatine inclination after the anterior retraction because the numeric value was reduced, but with no statistical significance.

Paiva et $\mathrm{al}^{21}$ also in cases treated with extraction of 4 premolars reported a statistically significant reduction of linear values (1-NA), however the reduction on angular values (1.NA), was not statistically significant, which is in agreement with the findings in this study.

On the lower dentoalveolar component, all variables related to lower incisors experienced statistically significant alteration (Table 1). It was verified a protrusion, vestibularization and extrusion of lower incisors (1-APog, IMPA, 1-GoGn, 1-NB, 1.NB). This can be explained by the use of intermaxillary elastics of Class II that were necessary in most patients at final stage. Side effects on the inclination of incisors in patients treated with intermaxillary elastics are widely reported in literature, confirming this supposition. ${ }^{19}$ On the other hand, Scott Conley and Jernigan ${ }^{25}$ did not find statistically significant alterations on IMPA.

By evaluating the dental relations, it was observed a reduction of the value of molar relation, pointing the increase of Class II molar relation, which was expected, for only two upper premolars were extracted, and the cases would be finished with a full Class II molar relation in both sides (Table 1). It was observed a significant improvement on the overbite which was also already expected, for the deep overbite was corrected during treatment with the use of reverse curve wires on the lower arch and accentuated on the upper arch, including during the anterior retraction (Table 1). The overjet reduced significantly with the treatment, which was also expected, because it was taken as criteria for inclusion on the sample that the patients presented an overjet of at least $5 \mathrm{~mm}$ and finished the treatment with the malocclusion corrected with canines in Class I relation and normalized overjet (Table 1).

Also on the evaluation of tissue profile results, the data presented an upper lip retrusion, verified on measures UL-SnPog, A-NPog, UL-E, and a lower lip retrusion on measure LL-E, however the variable LLSnPog did not present statistically significant difference despite presenting a tendency to reduction in its value which shows a tendency to lower lip retrusion, contradicting the expected lower lip protrusion due to vestibularization and protrusion verified on lower incisors (Table 1). These results are in agreement with the works presented in literature. ${ }^{25,27}$ Scott Conley and Jernigan ${ }^{25}$ also found an unexpected result. They assigned this reduction on the lower lip projection to the presence of an everted lower lip, because with a deep overbite, an accentuated overjet and a Class II dental relation, the lower lip may be artificially kept in a more protruded position trapped in the space between lower and upper incisors and after the upper incisors retraction, returns to its normal position.

Some authors that evaluated cases with extraction of two upper premolars, realized that according to the treatment protocol used, the lip thickness at the beginning of treatment, the vertical control and variety of facial patterns, the lips may be affected by dental moves on the anteroposterior direction, however the magnitude of this alterations is of difficult predictability. ${ }^{26,27}$

Several authors did not find significant differences on the alterations of soft tissue between groups treated with extraction of four premolars and without extractions ${ }^{7,30}$ while other authors observed a tissue profile retrusion. ${ }^{1,3,4}$

Considering that a retraction of upper incisors necessarily imply in a retrusion of the upper lip,${ }^{30}$ it is known that the muscle-skeletal-functional complex of the upper lip contributes for the variability observed on alterations of upper lip with the treatment protocol with premolars extractions. ${ }^{29}$

In this work the nasolabial angle did not present statistically significant alteration (Table 1). Despite the upper teeth retraction suggests that occurs an increase of the nasolabial angle, this result was not observed.

Some authors assign this result to nasal growth, occurring a down inclination of the columella and the pronasal, reducing the nasolabial angle. Theses authors assert that the nasolabial angle is formed by soft tissue (pronasal) and cartilage (columella), which continues to grow forth as well as the soft tissue of the upper lip and observed that only a small statistically insignificant change occurred of nasal base retraction (subnasal), therefore, if the projection of the upper lip tends to reduce, while the base nasal projection remains the same, the nasolabial angle must become more obtuse. ${ }^{1,7,30}$ 
Kocadereli ${ }^{16}$ and Uehara et $\mathrm{a}^{28}$ observed mean values statistically equal of the nasolabial angle both for patients that did not experience dental extraction and those who were submitted to extractions of four premolars. Tadic and Woods ${ }^{26}$ also did not find statistically significant alteration of the nasolabial angle in patients treated with extraction of upper first premolars.

However, Freitas et $\mathrm{ll}^{8}$ observed an increase of the nasolabial angle in cases treated with extraction of four premolars in a proportion of increase of nasolabial angle in $1,49^{\circ}$ for each millimeter of retraction on upper teeth which also was confirmed by other authors. ${ }^{27}$ Scott Conley and Jernigan ${ }^{25}$ also found statistically significant alterations of the nasolabial angle which had an increase of $6.38^{\circ}$.

Erdinç et $\mathrm{al}^{7}$ observed that the nasolabial angle reduced significantly in groups treated with extraction of four premolars and in groups without extractions these alterations were insignificant.

Despite the generalized idea that extractions cause an increase of the nasolabial angle, the results from this work are in agreement with latest conclusions of works mentioned above.

\section{CLINICAL CONSIDERATIONS}

The obtained results showed that profile alterations occur as effect of orthodontic treatment. How- ever, each patient must be individually analyzed so the professional can plan the treatment and instruct the patient about these aspects. Concomitantly, it allows the clinician a greater predictability of possible alterations that the treatment will cause and thus increase the percentage of success in this type of treatment and the patient's satisfaction.

The lower lip retrusion is an essential data when planning the treatment and its positioning must be evaluated in the beginning of treatment and verified if it is affected by the positioning of upper incisors, for this will lead to lower lip retrusion and the patient must be aware. Generally this detail go unnoticed by the clinician, for he only reports the upper lip retrusion due the chosen treatment does not include extraction on the lower arch.

\section{CONCLUSION}

Based on the evaluated sample and the used methodology, the alterations caused by extraction of two premolars on Class II division 1 malocclusion were:

»Maxillary retrusion, improvement of the maxillomandibular relation, increase of the anteroinferior facial height, upper incisors retrusion, vestibularization, protrusion and extrusion of lower incisors, besides the reduction of overbite and overjet.

" The profile alterations were: Reduction of the facial convexity and upper lip retrusion. 


\section{REFERENCES}

1. Basciftci FA, Uysal T, Buyukerkmen A, Demir A. The influence of extraction treatment on Holdaway soft-tissue measurements. Angle Orthod. 2004:74(2):167-73

2. Bowbeer GR. The 6 th key to facial beauty and TMJ health. Funct Orthod 1987:4(4):10-11, 13-15.

3. Bowman SJ. More than lip service: facial esthetics in orthodontics. J Am Dent Assoc. 1999:130(8):1173-81

4. Bravo LA, Canut JA, Pascual A, Bravo B. Comparison of the changes in facial profile after orthodontic treatment, with and without extractions. Br J Orthod. 1997:24(1):25-34.

5. Chua AL, Lim JY, Lubit EC. The effects of extraction versus nonextraction orthodontic treatment on the growth of the lower anterior face height Am J Orthod Dentofacial Orthop. 1993:104(4):361-8

6. Eirew HL. An orthodontic challenge. Int J Orthod. 1976;14(4):21-5.

7. Erdinc AE, Nanda RS, Dandajena TC. Profile changes of patients treated with and without premolar extractions. Am J Orthod Dentofacial Orthop. 2007:132(3):324-31

8. Freitas MR, Henriques JFC, Pinzan A, Janson GRP, Siqueira VCV. Estudo longitudinal das alterações do ângulo naso-labial, em jovens com Classe II, 1ำ divisão, que se submeteram ao tratamento ortodôntico corretivo. Ortodontia. 1999:32(1):8-16.

9. Gottlieb EL, Nelson AH, Vogels DS 3rd. 1990 JCO study of orthodontic diagnosis and treatment procedures. 1. Results and trends. J Clin Orthod 1991:25(3):145-56

10. Graber T, Vanarsdall R Jr. Ortodontia: principios e técnicas atuais. 3a ed. Rio de Janeiro: Guanabara Koogan; 2000

11. Janson G, Barros SE, de Freitas MR, Henriques JF, Pinzan A. Class II treatment efficiency in maxillary premolar extraction and nonextraction protocols. Am J Orthod Dentofacial Orthop. 2007:132(4):490-8.

12. Janson G, Brambilla Ada C, Henriques JF, de Freitas MR, Neves LS. Class II treatment success rate in 2- and 4-premolar extraction protocols. Am J Orthod Dentofacial Orthop. 2004;125(4):472-9.

13. Janson G, Camardella LT, Araki JD, de Freitas MR, Pinzan A. Treatment stability in patients with Class II malocclusion treated with 2 maxillary premolar extractions or without extractions. Am J Orthod Dentofacial Orthop. 2010;138(1):16-22

14. Janson G, Leon-Salazar V, Leon-Salazar R, Janson M, de Freitas MR. Long-term stability of Class II malocclusion treated with 2- and 4-premolar extraction protocols. Am J Orthod Dentofacial Orthop. 2009;136(2):154.e1-10; discussion 154-5
15. Janson G. Maria FR, Barros SE, Freitas MR, Henriques JF Orthodontic treatment time in 2- and 4-premolar-extraction protocols. Am J Orthod Dentofacial Orthop. 2006:129(5):666-71.

16. Kocadereli I. Changes in soft tissue profile after orthodontic treatment with and without extractions. Am J Orthod Dentofacial Orthop. 2002;122(1):67-72

17. Mailankody J. Enigma of Class II molar finishing. Am J Orthod Dentofacial Orthop. 2004;126(6):a15-16; author reply a16-17.

18. McNamara JA Jr. Components of class II malocclusion in children 8-10 years of age. Angle Orthod. 1981;51(3):177-202

19. Merrifield LL, Cross JJ. Directional forces. Am J Orthod. 1970:57(5):435-64

20. Oliveira GF, Almeida MR, Almeida RR, Ramos al Alterações dentoesqueléticas e do perfil facial em pacientes tratados ortodonticamente com extração de quatro primeiros pré-molares. Rev Dent Press Ortod Ortop Facial. 2008;13(2):105-14.

21. Paiva J, Rino Neto J, Batista K. Análise do lábio superior após o tratamento ortodôntico. Ortodontia. 2004;37(2):8-13

22. Proffit WR. Forty-year review of extraction frequencies at a university orthodontic clinic. Angle Orthod. 1994;64(6):407-14.

23. Proffit WR, Phillips C, Tulloch JF, Medland PH. Surgical versus orthodontic correction of skeletal Class II malocclusion in adolescents: effects and indications. Int J Adult Orthodon Orthognath Surg. 1992;7(4):209-20.

24. Rains MD, Nanda R. Soft-tissue changes associated with maxillary incisor retraction. Am J Orthod. 1982:81(6):481-8

25. Scott Conley R, Jernigan C. Soft tissue changes after upper premolar extraction in Class II camouflage therapy. Angle Orthod. 2006;76(1):59-65.

26. Tadic N, Woods MG. Incisal and soft tissue effects of maxillary premolar extraction in Class II treatment. Angle Orthod. 2007;77(5):808-16.

27. Talass MF, Talass $L$, Baker RC. Soft-tissue profile changes resulting from retraction of maxillary incisors. Am J Orthod Dentofacial Orthop. 1987:91(5):385-94.

28. Uehara SY, et al Perfil facial após tratamento de Classe II-1 com ou sem extrações. RGO: Rev Gaúch Odontol. 2007:55(1):61-8.

29. Waldman $\mathrm{BH}$. Change in lip contour with maxillary incisor retraction. Angle Orthod. 1982;52(2):129-34.

30. Zierhut EC, Joondeph DR, Artun J, Little RM. Long-term profile changes associated with successfully treated extraction and nonextraction Class II division 1 malocclusions. Angle Orthod. 2000;70(3):208-19. 